\title{
Spoof Nobels take researchers for a ride
}

Steve Nadis, Boston

Eleanor Maguire was in an apprehensive mood. She had just flown into Boston, Massachusetts, to collect an Ig Nobel Prize in Medicine at Harvard University. But just before the ceremony, she was having second thoughts. "What have I gotten myself into?" she asked herself aloud.

Earlier this year, Maguire, a neuroscientist at University College London, had barely heard of the Ig Nobels, which were awarded for the 13th time on 2 October by a selfappointed panel for "research that cannot or should not be reproduced". Maguire had no idea why she'd won - although the title of a paper she co-authored in 2000, "Navigationrelated structural change in the hippocampi of taxi drivers" (Proc. Natl Acad. Sci. USA 97, 4398-4403), might have offered her a clue.

In the paper, Maguire and her colleagues showed that the posterior hippocampus, thought to be a navigation centre in the brain, is enlarged in London taxi-drivers. What's more, the volume of the hippocampus correlates with years of experience in the cab. This research was no joke, as it suggested a capacity for structural plastic changes in healthy human brains - a finding with important clinical implications. Yet it plunged Maguire into an annual prize-giving ceremony bestknown for its frivolity and sophomoric gags.

This year, one lucky spectator won a date with a proper Nobel laureate, Richard Roberts (Physiology or Medicine, 1993), also known as Mr December in the 1997 "Studmuffins of Science" calendar. Another got to meet Stephen Wolfram, who promised to explain his intense 1,200-page tome $A N e w$ Kind of Science over a cup of tea.

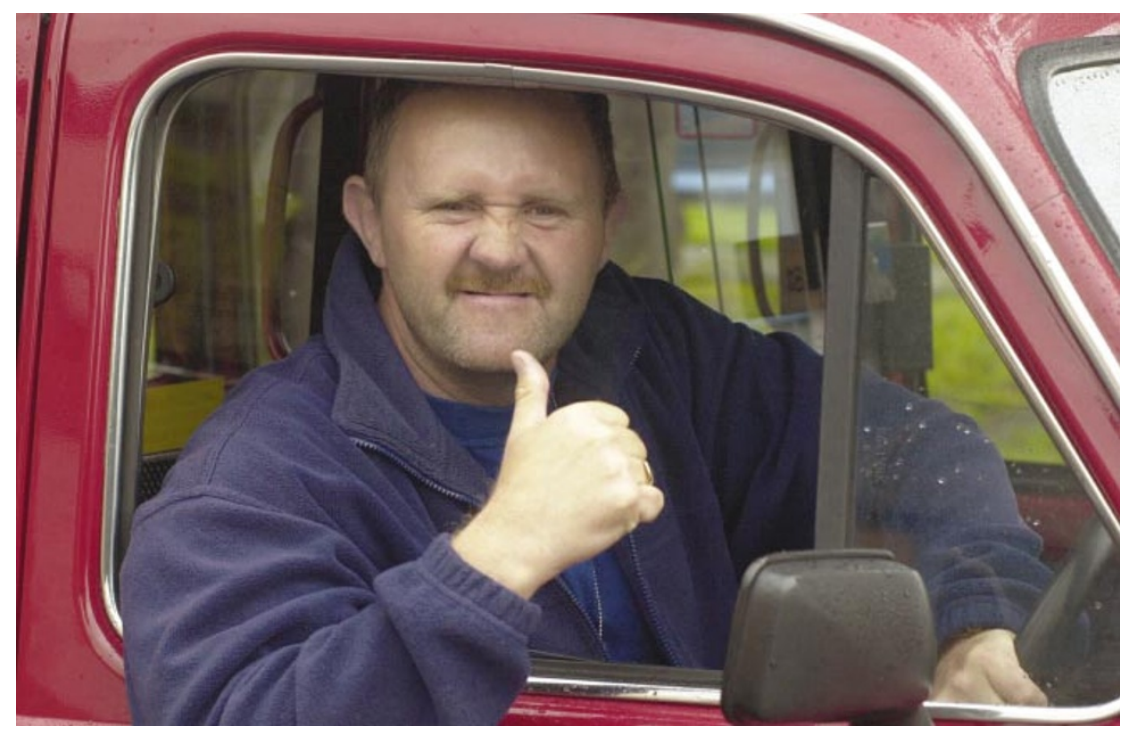

Fare play, guv: London cabbies have a big hippocampus, according to an Ig Nobel-winning study.

In a "24/7 nanolecture", geneticist Eric Lander summarized the Human Genome Project in 24 seconds — "The genome cost US $\$ 3$ billion and gave us three billion letters: one dollar a letter. Such a deal!" — and then, rather more successfully, in seven words: "Genome. Bought the book. Hard to read."

The physics Ig Nobel went to Australian investigators for "An analysis of the forces required to drag sheep over various surfaces" (Appl. Ergon. 33, 523-531; 2002). Yukio Hirose of Kanazawa University in Japan captured the chemistry award for his studies of a bronze statue that failed to attract pigeons.

Researchers at Stockholm University, Sweden, claimed the interdisciplinary prize for "Chickens prefer beautiful humans" (Hum. Nature 13, 383-389; 2002). And C.W. Moeliker of the Natuurmuseum in Rotterdam, the Netherlands, won the biology prize for documenting the first known case of homosexual necrophilia in the mallard duck (Deinsea 8, 243-247;2001).

In her acceptance speech, Maguire told the crowd that she got a $50 \%$ discount on a cab fare "for showing that taxi-cab drivers are special" - perhaps the first instance of anyone benefiting materially from winning an Ig. At the ceremony's end, she said: "Some of the other winners did amazing things with sheep, pigeons, chickens and mallard ducks. But for now I'll stick with taxi-drivers."

\section{Geologists seek to put an end to blind dates}

\section{Tom Clarke}

Earth scientists have decided it is time to talk time. At a meeting in Washington DC last week, experts in mass extinctions, ancient climate and the art of dating rocks got together to work out plans for a more accurate and complete geological timescale.

The researchers plan to establish an international network of laboratories that would use agreed standard procedures for dating rocks, and to which all Earth scientists would send samples of agreed quality from important sites. Over time, that would establish a database of reproducibly accurate dates for everything recorded in the Earth's rocks, from the evolution of ancient life to rapid climate-change events.

The project could take 15 years, and could fill in many gaps in our knowledge of
Earth's history, says Samuel Bowring, a geochronologist from the Massachusetts Institute of Technology in Cambridge and one of the meeting's organizers. "The record is hopelessly incomplete," he says.

That is partly because the most accurate techniques for dating are work-intensive and require more skill and money than most labs can spare. So researchers often simply estimate rock ages by comparing the fossils found in one stripe of rock to another of known age.

What's more, many historically important layers of rock were dated before the more accurate techniques were invented. Until recently, for example, the Cambrian explosion, from which most animal species emerged, was thought to have occurred some 575 million years ago over an unknown

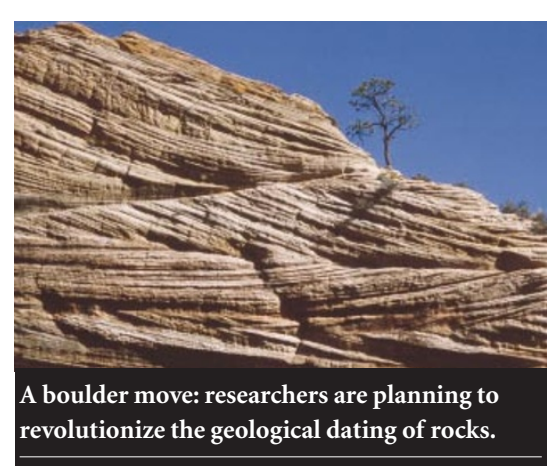

period of time. But the use of highly accurate uranium-lead isotope measurements allowed Bowring's lab to show that it actually began 544 million years ago and lasted just a few million years (Science 261, 1293-1298;

1993). Such information is crucial for 


\section{Judge's sacking rocks Everglades clean-up}

\section{Betsy Mason, Washington}

The Florida Everglades clean-up effort one of the world's largest and most hotly debated environmental projects - is in trouble this week, after the judge charged with overseeing the scheme was kicked out for alleged political bias.

The ousting on 23 September of Judge William Hoeveler of the US District court at Fort Lauderdale is the culmination of six months of bitter wrangling over desirable phosphorous levels in the Everglades. The 5,000 -square-kilometre wetland in southern Florida is home to at least 60 endangered species, including the American crocodile.

The removal of Hoeveler - largely brought about by sugar growers whose farms north of the Everglades are the source of phosphorus flowing into the swamp - has alarmed some supporters of the \$8-billion clean-up effort. "The scientific system has been undercut," claims ecologist Curt Richardson of Duke University in Durham, North Carolina.

In its natural state, the Everglades supported a unique ecosystem made up of plants and animals that thrive in nutrient-poor conditions. Adjusting the nutrient balance can cause radical changes to the ecosystem, including the invasion of cattails, which overrun native saw-grass and choke the flow of water through the region.

Ecologists want phosphorus levels to be kept below 10 parts per billion (p.p.b.), but levels are as high as 80 p.p.b. in some water flowing into the Everglades. As a result, a 'phosphorous front' has been gradually encroaching on the wetlands at around a kilometre per decade, says ecologist Evelyn Gaiser of Florida International University in

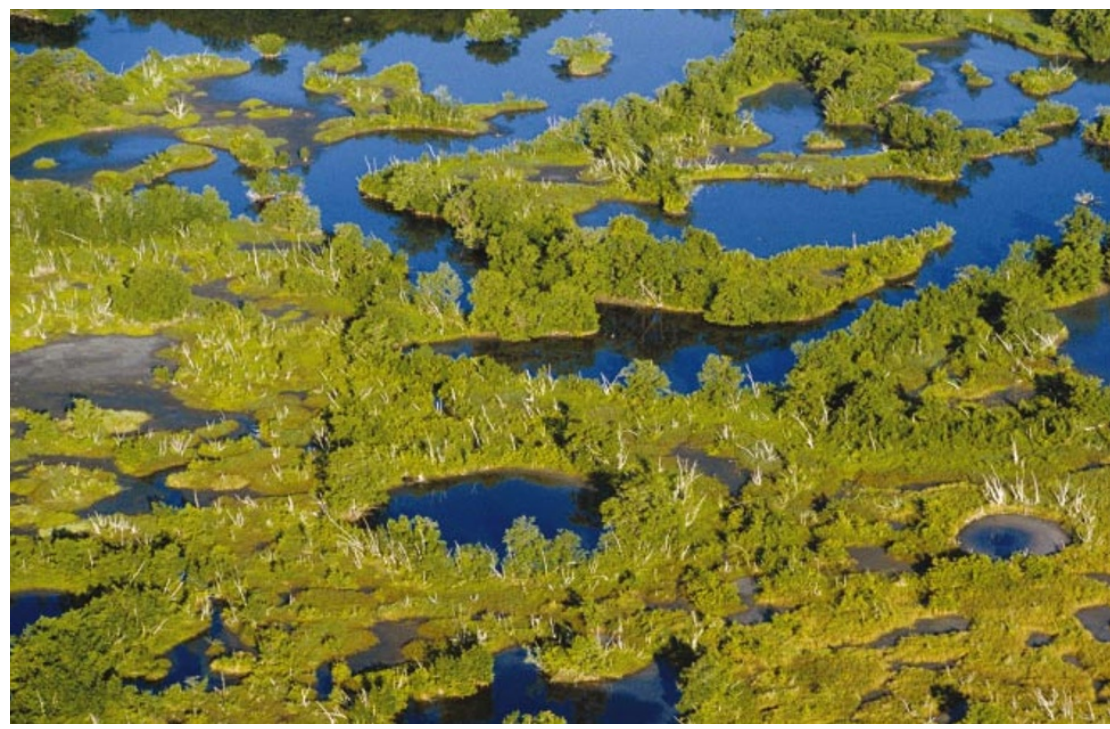

Bittersweet business: a flow of phosphorus from sugar farms poses a threat to Florida's wetlands.

Miami. "Every day counts," says Dan Childers, who studies the Everglades ecosystem at Florida International University in Miami. "As we wait, more and more of the Everglades will be impacted."

When the restoration project began in 1992, Florida's state government agreed to bring the levels of phosphorous in water entering the Everglades down to 10 p.p.b. by 2006 .

Since then, sugar farmers - who avoid using phosphorus-based fertilizers, but whose water-management practices cause the release of the chemical - have greatly reduced the amount of phosphorus leaving their farms. But the 2006 deadline is looming, and most experts agree that it is unlikely palaeontologists - determining exactly when extinction events began and ended can help to establish whether they were caused by a single catastrophic event or a slow change in the environment.

Geologists now want to repeat that process for other key events in the Earth's history. Last week's meeting, sponsored by the National Science Foundation (NSF), was held to start figuring out how to do this. The data would complement other NSF-funded geoinformatics projects already under way, including Chronos, which aims to match different layers of rock of the same age from around the world, and the Paleobiology Database (see Nature 424, 482-483; 2003), which looks at fossil finds.

Researchers are now putting together a proposal for how this project can be tackled.
Bowring believes that three new US labs will be required, at a cost of around $\$ 6$ million and with annual operating costs of between $\$ 2$ million and \$3 million.

"It's in everyone's best interest, so there's no reason why we shouldn't be able to get agreement," says Tony Fallick, who heads isotope dating at the Scottish Universities Research and Reactor Centre in Glasgow. Although the initiative is US-led, the lab work and results would be shared internationally.

The NSF has a new funding stream dedicated to efforts too big for one lab to handle. Geoinformatics is one such area, says Walter Snyder, section head for research grants in the NSF's Earth science division. "The burden is now on the community to agree on a common approach," he says. to be met. So in May, a law supported by the farmers to extend the deadline until 2016 was passed by the Florida legislature and signed by state governor Jeb Bush, brother of US president George W. Bush.

Hoeveler - whose court has overseen the restoration project from the outset - was quoted in the Florida press as saying that he was "deeply troubled by the content of the bill", and that Governor Bush had allowed the project to "fall into the hands of those who don't like the Everglades". Under a federal code of ethics that prohibits judges from appearing biased or commenting publicly on the merits of a pending case, the US Sugar Corporation of Clewiston, Florida, successfully filed for the judge's removal.

"The principle behind the original settlement was that no contribution to pollution was acceptable," says Neal McAliley, a former US Justice Department attorney on the Everglades case. "Implicit in the new law is the idea that some pollution is acceptable. In my view that represents a shift in thinking at a policy level."

The changes leave ecologists worried that delays could now undermine the entire restoration. But Gary Goforth, an environmental engineer at the South Florida Water Management District, the state agency that is implementing the project, says that most aspects of it are still ahead of schedule.

"It's not a date that matters," says Judy Sanchez, director of corporate communications at US Sugar. "It's progress that matters. And progress has been extraordinary."

Environmentalists remain unconvinced, however. "The sugar industry's interest is and always has been delay," says Thom Rumberger, chair of the Everglades Trust. "This is the ultimate delay." 